\title{
ERGONOMIC DESIGN OF THE WORKPLACE FOR FINAL QUALITY CONTROL
}

\author{
Matic BREZNIK ${ }^{1}$, Natasa Vujica HERZOG ${ }^{2 *}$
}

${ }^{1}$ BSH Nazarje, Slovenia, ORCID No: https://orcid.org/0000-0001-8519-434X

2 University of Maribor, Faculty of Mechanical Engineering, 2000 Maribor, Slovenia ORCID No: https://orcid.org/0000-0002-9242-2977

\begin{tabular}{ll}
\hline Keywords & Abstract \\
\hline Workplace design & The incidence of work-related musculoskeletal disorders remains high, and, as these \\
Ergonomic analysis & injuries have a high cost for companies and society, it is important to prevent them \\
OWAS Method & through ergonomic analysis and workplace design. The paper presents a case study \\
Final control workplace & control workplace is the last link between production and transportation to the \\
customer. The worker must inspect approximately 2,000 starter ring gears per shift & and ensures that the final products are in the condition expected by the customer. The \\
workflow is extremely monotonous and since the work positions are repetitive, \\
ergonomic analyses were conducted aiming to determine the strain and stress in the \\
workplace. \\
The aim of our research was to minimise occupational risk in the workplace through \\
the scientific design of workstations based on a methodical approach. The manual and \\
computerised owaS method was used to determine and estimate body postures during \\
the workday. It was found that certain postures lead to significant overuse, which \\
means that certain remedial actions are necessary during the work process to prevent \\
possible damage to the body. Computer aided workplace design represents a new and \\
faster approach in ergonomic workplace design. This approach is especially useful in \\
the design of new workplaces. We can easily eliminate possible stress on the worker \\
and potential injuries in less time before they occur.
\end{tabular}

\section{SON KALİTE KONTROLÜ İÇIN İSYERINIIN ERGONOMIK TASARIMI}

\begin{tabular}{l}
\hline Anahtar Kelimeler \\
\hline İsyeri tasarımı \\
Ergonomik analiz \\
OWAS Yöntemi \\
Bilgisayar simülasyonu \\
Issyeri son kontrolü
\end{tabular}

İsyeri son kontrolü

\section{Öz}

İş ile ilgili kas-iskelet sistemi rahatsızlıklarının görülme sıklığı yüksek olmaya devam etmektedir ve bu yaralanmalar işletmeler ve toplum için yüksek bir maliyete sahip olduğundan, bunların ergonomik analiz ve işyeri tasarımı yoluyla önlenmesi önemlidir. Makale, işyerinin son kontrolünde zorlanma ve stres açısından bir vaka çalıșması araștırmasını sunmaktadır. Son kalite kontrol çalıșma yeri, üretim ve müşteriye nakliye arasındaki son bağlantıdır. İşçi, vardiya başına yaklaşık 2.000 marş halkası dişlisini incelemeli ve nihai ürünlerin müşterinin beklediği durumda olmasını sağlamalıdır. İş akışı son derece monotondur ve çalışma pozisyonları tekrarlayıcı olduğu için işyerindeki zorlanma ve stresi belirlemeye yönelik ergonomik analizler yapılmıştır.

Araştırmanın amacı, iş istasyonlarının metodik bir yaklaşıma dayalı bilimsel tasarımı ile işyerinde mesleki riski en aza indirmektir. İş günü boyunca vücut duruşlarını belirlemek ve tahmin etmek için manuel ve bilgisayarlı OWAS yöntemi kullanılmıştır. Belirli duruşların önemli ölçüde aşırı kullanıma yol açtığı bulunmuş, bu da vücutta olası hasarı önlemek için çalışma sürecinde belirli iyileștirici eylemlerin gerekli olduğu anlamına gelmektedir. Bilgisayar destekli çalışma alanı tasarımı, ergonomik çalışma alanı tasarımında yeni ve daha hızlı bir yaklaşımı temsil etmektedir. Bu yaklaşım özellikle yeni iş yerlerinin tasarımında kullanışlıdır. İşçi üzerindeki olası stresi ve olası yaralanmaları meydana gelmeden daha kısa sürede kolayca ortadan kaldırabiliriz.

\begin{tabular}{llll}
\hline Araştırma Makalesi & & Research Article & \\
Başvuru Tarihi & $: 01.03 .2021$ & Submission Date & $: 01.03 .2021$ \\
Kabul Tarihi & $: 19.04 .2021$ & Accepted Date & $: 19.04 .2021$ \\
\hline
\end{tabular}

\footnotetext{
*Corresponding author e-mail: natasa.vujica@um.s
} 


\section{Introduction}

The goal of Ergonomics is to create safe, comfortable, and productive workplaces that take into account people's abilities and limitations at work, and adjust workloads to take into account individual heights, strength, abilities, speed, and other characteristics (Bhattacharya and McGlothlin, 2017). By ergonomic design of the workplace it is possible to adapt the work to the physical and mental characteristics of the person, and reduce or prevent negative effects on health (Polajnar et al., 2003, 2007, 2010; Andrejiova et al., 2012). Proper workplace design also includes human habits, to ensure that people work as productively, effectively and safely as possible. The social benefits of ergonomic workplace design are, therefore, numerous, ranging from improved worker health, reduced physical and mental workload, less pain and discomfort, fewer injuries, to improved motivation and greater job satisfaction.

There are also many economic benefits when manufacturing workplaces are designed according to ergonomic rules (Bhattacharya and McGlothlin, 2017). Typical manufacturing environments where ergonomic approaches can provide tangible and measurable results are workstations that are connected in lines, such as assembly lines (Slack at al., 2010). In assembly lines or other manufacturing lines that are focused on product, workers spend a lot of time performing the same repetitive tasks, and any error or delay can cause further problems. With proper ergonomic workplace design, we can achieve shorter cycle times, higher productivity, lower production costs, higher return on investment, higher product quality and flexibility, fewer human and system errors, less waiting during work hours, and lower injury costs (Vujica Herzog and Harih, 2019). The most important factors that should be considered in ergonomic workplace design are as follows:

1. The work environment with working conditions such as noise, heat, humidity, lighting, air velocity (Vujica Herzog at a., 2014, Polajnar, 2010),

2. Postures; especially awkward postures that can cause health problems. The OWAS observation method can be used for posture analysis,

3. The design of the manufacturing process, taking into account all the tasks performed by the worker, especially repetitive tasks. The weight of the manufacturing parts is also an important factor.

There are many ergonomic methods for evaluating postures (Vujica Herzog and Buchmeister, 2015), and they differ in the area of the body they evaluate (Roman-Liu, 2014; Spyropoulus, 2013). Some methods assess the strain of selected body parts independently, and other methods provide an overall assessment. Some methods focus on different work tasks, such as repetitive and non-repetitive tasks, and there are methods that assess static loads, such as loads where the same posture is held for an extended period of time. Manual handling is another type of task that should be given special consideration.

Because manual assesment tools are timeconsuming, new approaches to ergonomic job design are needed using computer-based tools that reduce assesment time and typically provide multiple methods for assessing worker' posture evaluation (e.g. Jack, Process Simmulate, Ergomas). Computerised tools are very useful, not only in the assessment of existing workplaces, but especially in the design of new workplaces. With this approach, we can easily eliminate possible worker strain and potential injuries in less time before they occur.

\section{Research Problem}

Most modern businesses divide tasks according to Smith's principle of division of labour, first mentioned and published as early as 1776 . Division of labour, also known as specialisation of labour, means that the way a product or service is produced is divided into a series of tasks performed by different workers, rather than all tasks being done by the same person (Slack at al., 2010). This principle is, therefore, also used in most manufacturing companies, and also in the enclosure production presented in our study.

For the final quality control workplace presented, short time movements are typical, and the products have different weights from 0.6 to $7.0 \mathrm{~kg}$ (internal information provided by company). The work is repetitive, and requires the full attention of the worker. Since there have been some complaints of back and neck pain and absences from work caused by health problems, we decided to observe all workers activities during the working day. Data from 10 workers who worked at the final quality control workstation were collected by number and product type, with corresponding weights and manipulation times of the product. The postures of the workers were analysed using the OWAS method.

In order to minimise the risk at work, the scientific design of workplaces based on a methodological approach is very important (Vujica Herzog et al., 2014).

\section{Methodology}

The following steps were taken for the problem analysis presented: 
- Workplace analysis and assessment; Analysis of the existent workstation dimensions in terms of work postures and perceptions of workers for individual and repetitive tasks;

- Workplace analysis considering the work environment; accurate measurements of noise, lighting, heat, humidity and air velocity were taken,

- The extended OWAS method (Karhu et al., 1977 and 1981) was used to evaluate the exposure to the different postures of the operators at the final control workstation. The observation was conducted 6 hours, four times per hour.

- The workplace under study was designed and analysed using the Jack software package from Technomatics,

- $\quad$ Several simulations were carried out using the OWAS analysis (manual and computer) to design a suitable final inspection workstation.

\section{Workplace for Final Quality Control}

The final quality control workstation is the last link between production and transportation to the customer. Therefore, the workplace requires a high level of concentration. The worker inspects and ensures that the final products are in the condition that the customer expects. Consequently, we have to improve the working conditions and remove all disturbing elements around the workplace that could have a negative impact on the worker.

The worker has to inspect about 2,000 pieces of starter ring gears per shift. The work schedule is extremely monotonous. During the shift, the worker has three repetitive tasks to complete:

(a) Micro - first, a piece is taken from the left pallet and held in a position in front of the worker. The arms are relaxed at the shoulders and bent at the elbows so that the worker can get a good look at the piece being inspected. Then the piece is turned over three times to make sure that all sides have been inspected and that the piece has no defects. If the piece passes inspection, it is then stacked into the correct pallet. If a defect is found, the worker removes the piece and places it on the pallet designated for scrap. Throughout the micro task, the worker tilts his head slightly forward.

It takes 9 seconds to inspect each piece. Thus, the total time of the micro-task of the shift is 300 minutes.

A great need for improvement has already been identified and improvements were implemented. The worker now spends about equal time in sitting and standing position. The worker decides when the change of position is required.

b) Macro - the pallet must be prepared by placing a protective paper and film on the bottom to prevent damage during transportation. Then the worker picks up about 11 pieces at a time and stacks them in the prepared pallet. The pieces are stacked in 7 different columns. During stacking, the worker puts a sheet of intermediate paper, which absorbs moisture and has an anti-corrosion effect.

The bending of the lower back of the worker while stacking the parts is adjusted to the height of the column in the pallet. Therefore, there is a big difference in the bending of the lower back.

Stacking the parts on the pallet takes about 300 seconds per pallet. So, the total time of the macro task of the shift is 20 minutes.

(c) Replacing the pallet - after stacking is complete, the empty pallet must be dragged to a collection point 10 metres away. It takes about one minute to replace a pallet. The total time for replacing the pallets is about 4 minutes per shift.

The remaining time of the shift is very important as it is necessary to stretch, walk and relax the muscles as often as possible.

At the final quality control workstation, 10 workers perform the process. The data of each worker were collected. They consisted of the number of parts moved and the type of each part inspected by a particular worker. The mass of each type was then multiplied by the number of parts inspected. The result was multiplied by two, since each part must be moved twice. The result shows the weight that the worker moved during the selected working time.

The efficiency of the worker was also calculated in addition. This was achieved by comparing the effective and normative time that the worker performed. It must be taken into account that the inspection of different parts is of different complexity. Therefore, direct calculation of the worker's efficiency is not the best indicator of actual efficiency. The collected data are divided into two time frames, 6 and 27 working days (Tables 1 and 2).

Table 1. One Week Period (6 working days).

\begin{tabular}{cccccc}
\hline Worker & $\begin{array}{c}\text { Inspected } \\
\text { pieces }\end{array}$ & $\begin{array}{c}\text { Moved } \\
\text { weight } \\
{[\mathrm{kg}]}\end{array}$ & $\begin{array}{c}\text { Normative } \\
\text { time [h] }\end{array}$ & $\begin{array}{c}\text { Effective } \\
\text { time [h] }\end{array}$ & $\begin{array}{c}\text { Worker's } \\
\text { efficiency } \\
{[\%]}\end{array}$ \\
\hline 020 & 6841 & 11830,02 & 37,15 & 32,00 & 116,09 \\
130 & 8436 & 14912,68 & 49,78 & 38,50 & 129,30 \\
148 & 8140 & 26081,32 & 39,30 & 33,00 & 119,09 \\
237 & 5040 & 20646,87 & 23,78 & 36,50 & 65,15 \\
299 & 5521 & 11248,13 & 32,41 & 23,75 & 136,46 \\
488 & 8915 & 14711,30 & 47,39 & 42,50 & 111,51
\end{tabular}




\begin{tabular}{rccccc}
503 & 7998 & 19664,61 & 45,49 & 38,00 & 119,71 \\
564 & 9830 & 12003,20 & 57,38 & 38,67 & 148,38 \\
581 & 5720 & 6451,72 & 33,77 & 37,01 & 91,25 \\
583 & 12968 & 18206,36 & 73,38 & 44,66 & 164,31 \\
616 & 11833 & 14600,07 & 70,60 & 43,92 & 160,75 \\
\hline
\end{tabular}

Table 2. One Month Period (27 working days).

\begin{tabular}{cccccc}
\hline Worker & $\begin{array}{c}\text { Inspected } \\
\text { pieces }\end{array}$ & $\begin{array}{c}\text { Moved } \\
\text { weight } \\
{[\mathrm{kg}]}\end{array}$ & $\begin{array}{c}\text { Normative } \\
\text { time }[\mathrm{h}]\end{array}$ & $\begin{array}{c}\text { Effective } \\
\text { time [h] }\end{array}$ & $\begin{array}{c}\text { Worker's } \\
\text { efficiency } \\
{[\%]}\end{array}$ \\
\hline 020 & 33218 & 72501,34 & 192,79 & 157,50 & 122,41 \\
130 & 40849 & 72029,76 & 247,69 & 180,00 & 137,60 \\
148 & 24706 & 51555,36 & 143,96 & 124,50 & 115,60 \\
237 & 17591 & 56202,42 & 88,53 & 118,50 & 74,70 \\
299 & 28981 & 55958,12 & 168,24 & 136,75 & 123,00 \\
488 & 35756 & 62113,52 & 151,72 & 135,50 & 112,00 \\
503 & 39105 & 69695,78 & 225,17 & 169,50 & 132,80 \\
564 & 43830 & 59905,7 & 276,62 & 181,60 & 152,30 \\
581 & 34051 & 53070,62 & 206,14 & 184,01 & 112,00 \\
583 & 58883 & 88633,44 & 329,39 & 191,50 & 172,00 \\
616 & 46990 & 62269,08 & 292,28 & 190,40 & 153,50 \\
\hline
\end{tabular}

\section{OWAS Method}

The Ovaco Working Analysing System (OWAS) method is a posture monitoring method (Karhu et al., 1977 and 1981; Landekić at al., 2019; Helling at al., 2018 and 2020). This method originated in the Finnish steel industry, where workers' postures were analszed. As the method was initially successful, it was developed and modified further. It is considered a viable method for identifying and evaluating work postures. The OWAS method consists of two parts: An observation technique for classifying postures, and a set of criteria for redesigning work methods and workplaces. Postures are classified into 28 positions, including those of the back (four positions), upper limbs (four), hands (three), lower limbs (nine), head and neck (five), and load or force handled (three).

For each of these positions, there are predefined high and low risk postures that are coded by the observer. After calculating the time the worker takes these postures, the final step is to assign a four-level action code for improving the task (changes are not required, changes are required immediately, changes are required in the near future, and intensive observation is required).

Manual and computerised OWAS analyses were performed for the presented problem. We observed workers' movements for two selected operations, called "micro" and "macro".

\section{Manual OWAS Procedure}

A video was created of an inspection cycle. The video was later paused every second, and all postures were entered into the OWAS spreadsheet. The results were the percentages of the different postures used by the worker to complete the cycle of an inspection.

\section{Human Simulation Jack}

A 3D model of the workplace was created in Human simulation Jack and several ergonomic analyses were performed.

\section{Workplace Analysis And Results}

Tables 3 and 4 show the results of the OWAS observation method with the calculated percentage of each position (Equation 1) and the time of duration (Equation 2), where $\sum \mathrm{Fp}$ represents the sum of each body position and $\left(\sum \mathrm{Fs}\right)$ is the sum of all body positions within each group of work positions.

$$
\begin{aligned}
& p=\frac{\sum F_{p} \cdot 100}{\sum \mathrm{F}_{S}}\lceil \%\rceil \\
& t_{p}=\frac{450 \cdot p}{100}\lceil\mathrm{~min}\rceil
\end{aligned}
$$

The obtained results were compared with the recommended measurements, and the results are presented with signs in Tables 3 and 4.

In the micro task, no position is taken often enough to require immediate intervention and ergonomic improvement of the workstation. However, the warning levels are reached, where action must be taken in the foreseeable future. These are in postures 2.2, 4.2, 5.2 and 6.1.

In the macro task, posture 1.2 is taken so frequently that immediate intervention and ergonomic improvement is required of the workplace. It would be impossible to work in these conditions, but the macro part takes up a smaller part of the working time and this makes it bearable. Changes to the workplace are also needed in the foreseeable future. Evidence that action is needed in the foreseeable future is also found in postures 2.2, 4.2 and 6.2.

The task of pallet exchange is not discussed, due to the short time and no critical movement.

After reviewing the whole work process, it was evaluated that it meets the required conditions of the Ergonomics standard. Nevertheless, some changes are required in the foreseeable future to avoid injuries due to the monotony of the work process. 
These changes would eliminate the problems studied by the method used.

Table 3. OWAS - Calculated Results with Recommended Measures For 'Micro' Tasks

\begin{tabular}{|c|c|c|c|c|c|c|c|c|c|c|}
\hline \multirow[b]{3}{*}{$\begin{array}{l}\text { Body } \\
\text { Parts }\end{array}$} & \multirow{2}{*}{\begin{tabular}{|c}
$\begin{array}{c}\text { Thoraxlumb. } \\
\text { spine }\end{array}$ \\
1.1 \\
\end{tabular}} & \multicolumn{3}{|c|}{ Upper limb } & \multicolumn{3}{|c|}{ Hands } & \multirow{2}{*}{$\begin{array}{l}\text { Lower } \\
\text { limb } \\
4.2\end{array}$} & \multicolumn{2}{|c|}{ Head } \\
\hline & & 2.1 & 2.2 & 2.3 & 3.1 & 3.2 & 3.3 & & 5.1 & 5.2 \\
\hline & \} & 杲 & 尔 & $\lambda$ & $\triangle$ & $\Lambda$ & $\angle$ & 9 & 9 & $V^{\circ}$ \\
\hline Nr. of $\mathrm{m}$. & 14 & 2 & 10 & 2 & 8 & 0 & 5 & 14 & 8 & 6 \\
\hline$p_{i}[\%]$ & 100,0 & 14,3 & 71,4 & 14,3 & 61,5 & 0,0 & 38,5 & 100,0 & 57,1 & 42,9 \\
\hline$t_{p i}[\mathrm{~min}]$ & 450,0 & 64,3 & 321,4 & 64,3 & 276,9 & 0,0 & 173,1 & 450,0 & 257,1 & 192,9 \\
\hline Measure & $\square$ & $\square$ & $\Delta$ & $\bullet$ & $\square$ & $\square$ & $\square$ & 0 & $\square$ & $\bullet$ \\
\hline
\end{tabular}

Table 4. OWAS - Calculated Results with Recommended Measures For 'Macro' Tasks

\begin{tabular}{|c|c|c|c|c|c|c|c|c|c|c|c|}
\hline \multirow[b]{3}{*}{$\begin{array}{l}\text { Body } \\
\text { Parts }\end{array}$} & \multicolumn{2}{|c|}{$\begin{array}{c}\text { Thoraxlumb. } \\
\text { spine }\end{array}$} & \multicolumn{4}{|c|}{ Upper limb } & \multicolumn{2}{|c|}{ Hands } & \multirow{2}{*}{$\begin{array}{c}\text { Lower limb } \\
4.2\end{array}$} & \multicolumn{2}{|c|}{ Head } \\
\hline & 1.1 & 1.2 & 2.1 & 2.2 & 2.3 & 2.4 & 3.1 & 3.3 & & 5.1 & 5.2 \\
\hline & L & {[} & 京 & 只. & 9 & 19. & $\Delta$ & $\angle$ & & 9 & \%. \\
\hline Nr. of m.. & 7 & 15 & 5 & 13 & 2 & 1 & 15 & 5 & 21 & 20 & 1 \\
\hline$p_{i}[\%]$ & 31,8 & 68,2 & 23,8 & 61,9 & 9,5 & 4,8 & 75,0 & 25,0 & 100,0 & 95,2 & 4,8 \\
\hline$t_{p i}[\mathrm{~min}]$ & 143,2 & 306,8 & 107,1 & 278,6 & 42,9 & 21,4 & 337,5 & 112,5 & 450,0 & 428,6 & 21,4 \\
\hline Measure & $\square$ & $\bullet$ & 口 & $\bullet$ & $\square$ & $\square$ & 口 & $\square$ & $\bullet$ & 口 & 口 \\
\hline
\end{tabular}

Legend: $\square$-changes are not required $\boldsymbol{\Delta}$ changes are required immediately $\bullet$ - changes are required in near future $\star$ - intensive observation is required

The computer- aided simulation using the Jack OWAS analysis produced similar results to the manually performed OWAS analysis. Although for the computer-aided simulation, the accurate construction of the body movements is timeconsuming, this approach allows us to analyse the worker's movements later, much more easily with different analyses. Additional analysis was also conducted to increase the credibility of the research conducted.

The entire micro-task is rated code 4111 . This means that the workstation is not in a critical condition, but action must be taken in the foreseeable future (Figure 1).

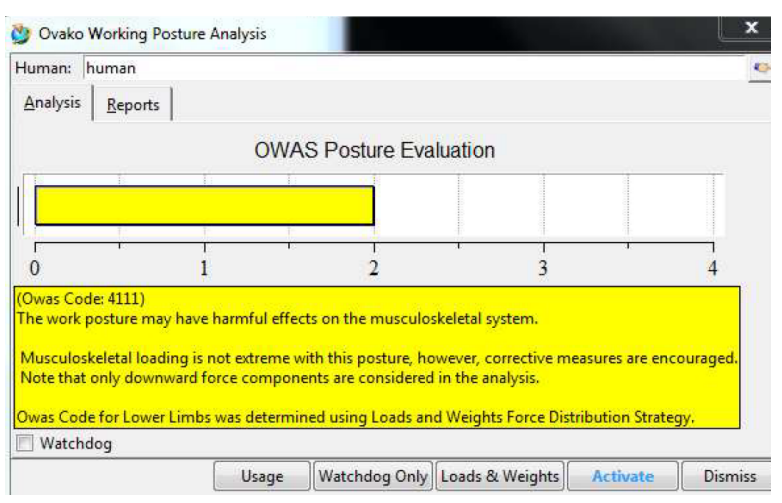

Figure 1. Results of OWAS Analysis for Micro Task

During the picking process the worker is bending, and the results of the OWAS analysis show that the posture could be harmful to the worker, and corrective action must be taken as soon as possible (Figure 2). 


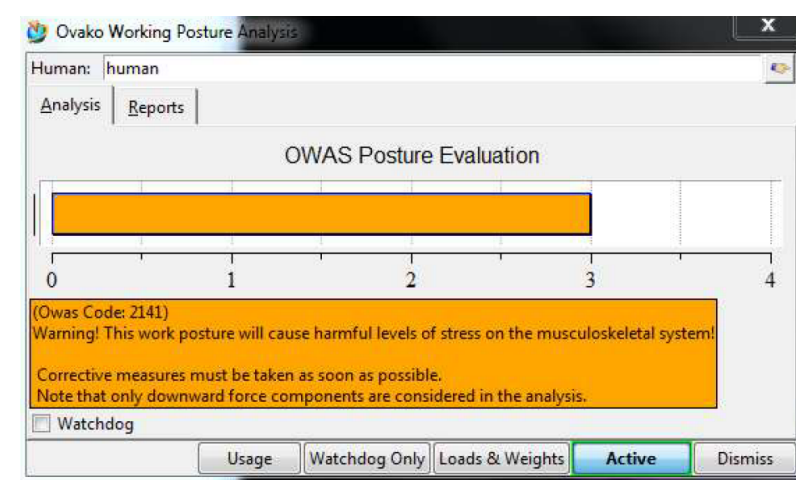

Figure 2. Results of OWAS Analysis for Macro Task

An analysis of the maximum allowable load was performed in addition to the OWAS method for the macro part. The lower limit at which $10 \%$ of the female population would consider the load too heavy to carry is $13 \mathrm{~kg}$ (Figure 3).

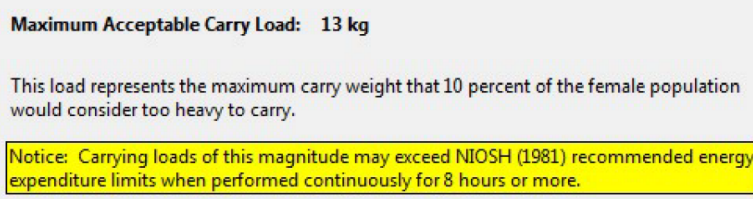

Figure 3. Macro Task - Maximum Acceptable Load

Figure 4 shows the additional results of lower back analysis performed using Jack. The results show low risk of low back injury for most healthy workers.

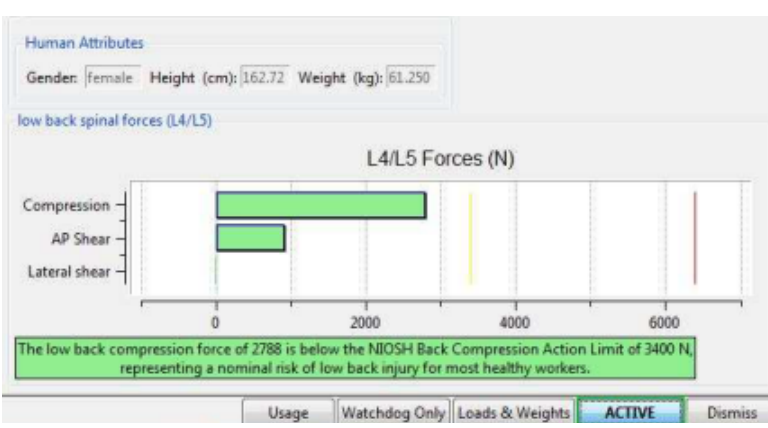

Figure 4. Results of Lower Back Analysis

\section{Suggestions for New Workplace Design}

Based on the results of the various ergonomic analyses, the following improvements were proposed:

(a) Appropriate equipment for workers.

The comfort of the worker in a workplace where concentration is required is necessary. Therefore, high quality equipment for the workers is imperative:

- High quality gloves that do not tear.

- An ergonomically designed seat that forces workers into the correct posture, and

- Enabling regular visual inspection and funding for corrective eyewear.

b) Lifting table

The most difficult movement for a worker to perform is the deep bow in the macro task. The simplest solution would be to use a U-section lift table that allows easy access of the hand lift truck. This also eliminates the risk of knocking over a column of stacked parts.

c) Rotation of workers

Due to the monotony of the micro task, it may not be possible to eliminate all risks. Then rotation of workers at different workstations is required. This method also met with great approval from the workers, as difficult tasks are distributed and they get rid of monotony, which leads to loss of concentration in an eight-hour working day.

Another positive aspect is that the usefulness of the workers is increased as they are trained to work on more than one workstation. This allows for easier reorganisation of staff when someone is absent or needs to be replaced.

d) Construction of quality control facilities

Since final inspection work is a very important part of production, it is important to find a quality solution to the problem of workplace disturbances. The best conditions would be provided by building a new area completely isolated from production.

e) Automation of the macro tasks

A "control line" was designed in order to achieve ergonomic and optimisation improvements. The macro task is unnecessary, and adds no value to the final product. Therefore, it should be completely automated. For easier visualisation of the new control line, a 3D model was created in Solidworks 2016 (Figure 5). 


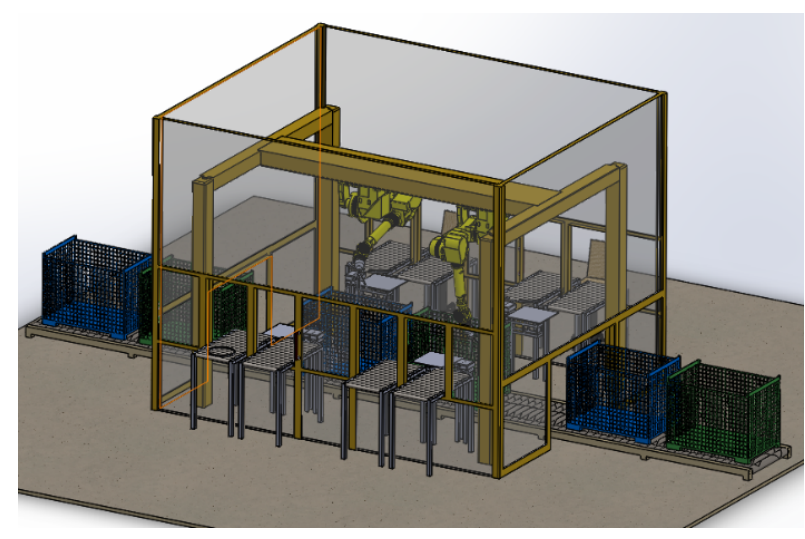

Figure 5. 3D Model of The New Control Line

The worker has the next new tasks to do:

- Prepare the bin at the beginning of the main conveyor belt before checking all the parts in the current process,

- Inspect the pieces delivered by the robot and the secondary conveyors,

- Remove the containers at the end of the main conveyor before all the pieces in the current process are inspected, and

- Inspect the work station, and respond properly to any malfunctions in the control line.

The new workstation design was also reviewed using the Jack software package, and the results of the posture analyses show that the positions of workers in all three phases (picking, product inspection and disposal) are now normal and neutral (Figures 6 and 7). As shown by the results of the OWAS analysis, the new control line eliminates all the irregularities that we found in the first analysis, and provides a safe and healthy workplace.

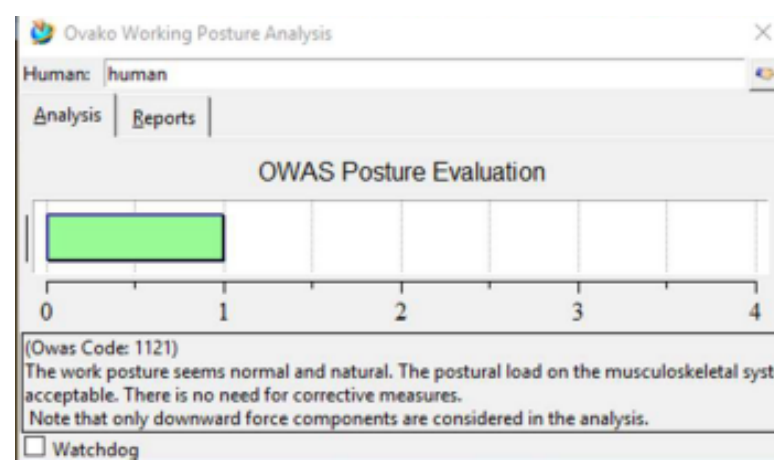

Figure 6. OWAS Results Using Jack

\section{Conclusions}

Since a poorly designed workplace can have longterm negative effects on the health of employees (musculoskeletal disorders - MSD), it is very important how a workplace is designed and organised (Edtmayr et al., 2011; Fritzsche et al., 2014; Kaljun, \& Dolšak, 2012; Ojsteršek et al., 2020; Panush, 2017; Vujica Herzog \& Harih, 2019; Wells et al., 2007). Short time movements are typical for the presented job of final quality control. The work is repetitive, and requires the full attention of the worker. The manual and computerised OWAS method was used to determine and assess postures during the workday. It was found that certain postures lead to significant overuse. Results for Micro and Macro part confirmed workers complaints of back and neck pain (posture could be harmful to the worker, and corrective action must be taken as soon as possible). Based on the results of the ergonomic analyses, several improvements were proposed aimed at avoiding overexertion of workers and ensuring a safe and healthy working environment: appropriate equipment for workers, lifting tables, rotation of workers, construction of quality control facilities and automation of macro tasks. The new workplace design was confirmed by computerised OWAS analysis, which shows that the workers' positions are normal and neutral. The new control line eliminates all the irregularities that we found in the first analysis, and provides a safe and healthy workplace.

As the main contribution of the presented case study research, the new and faster approach to ergonomic workplace design can be pointed out using computer-based tools, which reduce the evaluation time and provide multiple methods for evaluating workers postures compared to manually performed ergonomic analyses. In addition to the advantages of the detailed case study presented, this approach also has some limitations. The solutions presented were obtained for this particular environment and cannot be directly transferred to another environment. However, the ideas presented can be generalised and used in other workplaces with some adjustments.

\section{Acknowledgement}

This work was supported financially by the Slovenian Research Agency in the framework of Grant P2-0190.

\section{Conflict of Interest}

No conflict of interest was declared by the authors. 

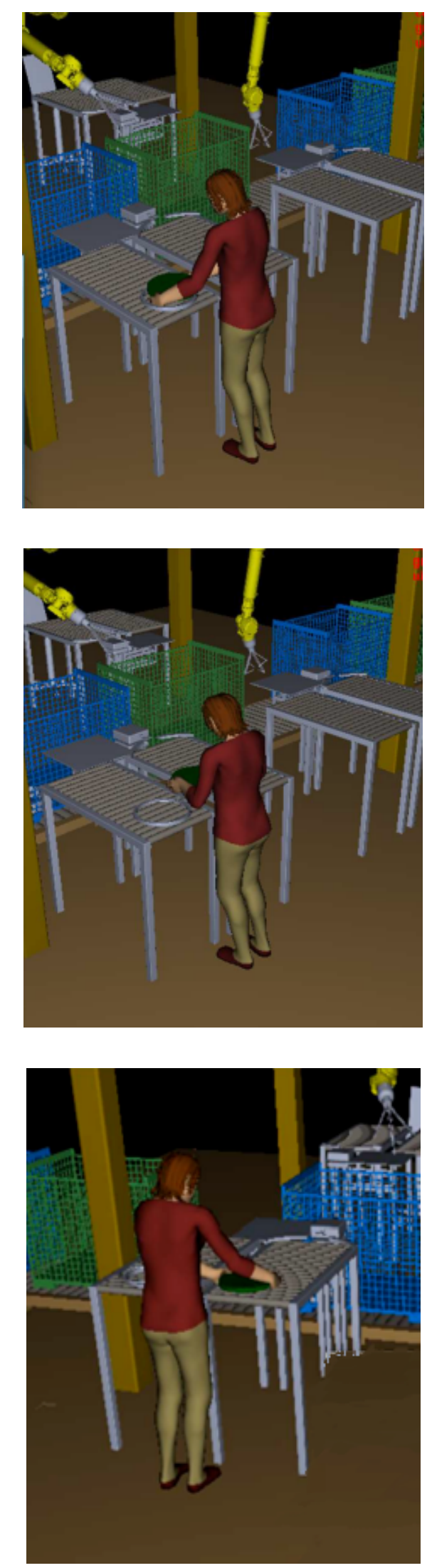

Figure 7. Worker's positions during work

\section{References}

Andrejiova, M., Kralikova, R., Wessely, E., Sokolova, H. (2012). Assesment of the Microclimate in the Work Environment, Chapter 42 in DAAAM International Scientific Book 2012, pp. 509-516, B. Katalinic (Ed.), Published by DAAAM International, ISBN 978-3-901509-86-5, ISSN 1726-9687, Vienna, Austria.

Bhattacharya, A., McGlothlin, J., D., (2017). Occupational Ergonomics, Theory and Application, $2^{\text {nd }}$ ed. CRCPress, Taylor and Francis Group, Boca Raton, USA.

Edtmayr, T., Kuhlang, P., Sihn, W. (2011). Methodical approach to designing workplaces and increasing productivity based on Value Stream Mapping and Methods - Time measurement, Transactions of FAMENA, 35 (1), 91-99.

Fritzsche, L., Wegge, J., Schmauder, M. (2014). Good ergonomics and team diversity reduce absenteeism and errors in car manufacturing, Ergonomics, 57 (2), 148-161.

Helling, T., Mertens, A., Brandl. (2018). The interaction effect of working postures on muscle activity and subjective discomfort during static working postures and its corrwlation with OWAS, International Journal of Industrial Ergonomics, $68,25-33$.

Helling, T., Johnen, L., Mertens, A., Nitsch, V., Brandl, C. (2020). Prediction model of the effect of postural interactions on muscular activity and perceived exertion, Ergonomics, 63 (5), 593-606.

Kaljun, J., Dolšak, B. (2012). Improving Products' Ergonomic Value Using Intelligent Decision Support System, Journal of Mechanical Engineering, 58 (4), 271-280.

Karhu, U., Kansi, P., Kuorinka, I. (1977). Correcting working postures in industry: a practical method for analysis. Applied Ergonomics, 8 (4), 199-201, ISSN: 0003-6870.

Karhu, O., Harkoen, R., Sorvali, P., Vespalainen, P. (1981). Observing working postures in industry: examples of OWAS application. Applied Ergonomics, 12 (1), 13-17, ISSN: 0003-6870.

Landekić, M., Katuša, S., Mijoč, D., Šporčić, M. (2019). Assessment and Comparison of Machine 
Operators' Working Posture in Forest Thinning, South-East European Forestry, 10(1), 29-37.

Ojsteršek, R., Ačko, B., Buchmeister, B. (2020) Simulation study of a flexible manufacturing system regarding sustainability. International journal of simulation modelling, 19 (1), 65-76.

Panush, R. S. (2017). Occupational and recreational musculoskeletal disorders Kelley and Firestein's Textbook of Rheumatology (Tenth Edition), 520532, Elsevier.

Polajnar, A., Verhovnik, V., Sabadin, A., Hrašovec, B. (2003). Ergonomics, Faculty of Mechanical Engineering, ISBN 86-435-0550-1, Maribor.

Polajnar, A., Verhovnik, V. (2007). Design of Work and Workplaces in Practice, $2^{\text {nd }}$ Edition, Faculty of Mechanical Engineering, ISBN 86-435-0305-3, Maribor.

Polajnar, A., Leber, M., Vujica Herzog, N. (2010). Muscular-skeletal diseases require scientifically designed sewing workstations, Strojniski vestnik Journal of Mechanical Engineering, 56 (1), 31-40.

Roman-Liu, D. (2014). Comparison of concepts in easy-to use methods for MSD risk assessment, Applied Ergonomics, 45, 420-427.

Slack, N., Chambers, S., Johnston, R. (2010). Operations management, $6^{\text {th }}$ ed. Pearson Education, England.

Spyropoulus, E., Chroni, E., Katsakiori, P., Athanassiou, G. (2013). A quantitative approach to assess upper limb fatigue in the work field, Occupational Ergonomics, 11, 45-57.

Vujica Herzog, N., Buchmeister, B. (2015). The review of ergonomics analysis for body postures assessment, Chapter 14 in DAAAM International Scientific Book 2015, pp. 153-164, B. Katalinic (Ed.), Published by DAAAM International, ISBN 978-3-90150998-8, ISSN 1726-9687, Vienna, Austria.

Vujica Herzog, N., Harih, G. (2019), Decision support system for designing and assigning ergonomic workplaces to workers with disabilities. Ergonomics, [Print ed.], 62 (12), 1-13.
Vujica Herzog, N., Vujica Beharić, R., Beharić, A., Buchmeister, B. (2014) Ergonomic analysis of ophthalmic nurse workplace using 3D simulation. International journal of simulation modelling, 13 (4), 409-418.

Wells, R., Mathiassen, S. E., Medbo, L., Winkel, J. (2007). Time - a key issue for musculoskeletal health and manufacturing, Applied Ergonomics, $38,733-844$. 